DOI: https://doi.org/10.32839/2304-5809/2021-5-93-14

УДК 378.013

Ткаченко I.А., Ткаченко А.M.

Лозівська фрілія

Харківського державного автомобільно-дорожнього коледжу

\title{
КОМПЕТЕНТНІСНИЙ ПІДХІД У НАВЧАЛЬНІЙ ДІЯЛЬНОСТІ ВНЗ
}

\begin{abstract}
Анотація. У статті розглядаються основні принципи компетентнісного підходу в сучасній освіті, етапи його становлення, склад мотиваційної компетенції в галузі навчання фрахівців, характерологічні ознаки ключових компетенцій. Однією з головних науково-методичних проблем, що постають перед вишами в зв'язку з переходом на нові стандарти, за основу яких взято компетентнісний підхід, $є$ розробка вітчизняної концепції компетентнісного навчання, змісту, типологій та рівнів самих компетенції в системі вищої професійної освіти. Багато положень компетентнісної освіти ще не стали предметом практичної педагогіки. Тому сьогодні для реалізації компетентнісного підходу необхідно спиратися на міжнародний освітній досвід і враховувати необхідність його адаптації до традицій і потреб країни. Перехід до компетентнісного підходу у вищій освіті дозволяе не просто накопичувати знання з дисциплін, які викладаються, а стимулюе творче, креативне їх використання, що дозволяе студенту бути мобільним в освітньому середовищі, як країни, так і світу, а випускникові вишу стати затребуваним і конкурентноспроможним на ринку праці.
\end{abstract}

Ключові слова: принципи і етапи становлення компетентнісного підходу, особистісно-орієнтовану, генезісную модель освіти, знання, вміння і навички, гностичний і аксіологічний компоненти компетенції, мотивація.

Tkachenko Irina, Tkachenko Andrii Lozov branch Kharkiv State Automobile and Road College

\section{COMPETENCE APPROACH IN EDUCATIONAL ACTIVITIES OF HIGHER EDUCATION INSTITUTIONS}

Summary. The article considers the basic principles of the competence approach in modern education, stages of its formation, the composition of motivational competence in the field of training, characteristics of key competencies. The main purpose of this work is to develop a concept methodological bases for improving the efficiency of professional training of state and municipal managers. training, content, typologies and levels of competence in the system of higher professional education. Many provisions of competency education have not yet become the subject of practical pedagogy. Therefore, today the implementation of the competency approach must be based on international educational experience and take into account the need to adapt it to the traditions and needs of the country. The competency approach stimulates the development of new technologies for assessing the quality of education. It is learning outcomes, not didactic units of educational content that will become the norm of its quality. Currently, the assessment of the quality of education includes not just the supply of ready-made knowledge, but the active cognitive and practical work of the students themselves. The professional demand for specialists in the labor market is the main idea of the Bologna Process and one of the main goals of creating a single system of European higher education, which solves the problems of labor mobility. The advantage of the competency approach is that it allows flexibility and autonomy in the structure and content of the curriculum. Based on this, we can conclude that today the higher education system should be based more on personality-oriented, genesis model of education, which forms competencies, than simply on the transfer of knowledge and the formation of a set of skills. The transition to competence approach in higher education allows not only to accumulate knowledge of the disciplines taught, but stimulates their creative, creative use, which allows the student to be mobile in the educational environment, both country and world, and the graduate to become in demand and competitive in the labor market.

Keywords: principles and stages of development of a competence approach, student-centered, the model of education, knowledge and skills, Gnostic and axiological components competence, motivation.

Постановка проблеми. У сучасній вітчизняній педагогіці відомо досить велике число різних підходів, що лежать в основі навчального процесу у вишах. Стратегічним напрямком до змісту освітнього процесу е компетентнісний підхід. «Сучасний стрімкий розвиток компетентнісного підходу, - зазначає А.М. Новиков, - обумовлений усвідомленням у суспільстві необхідності надання освіті діяльнісної спрямованості» [1, с. 9].

Входження України до Болонського процесу зобов'язуе організаторів вищої освіти поетапно реалізовувати складові існуючої системи единого освітнього простору, де виразною ознакою її змісту є розбудова на компетентнісно-оріентованій основі, що зумовлено кількома причинами: по-перше, переходом світової спільноти до інформаційного суспільства, де пріоритетним вважається не просте накопичення студентами знань та предметних умінь і навичок, а й формування уміння вчитися, оволодіння навичками пошуку інформащії, здатності до самонавчання упродовж життя, де ці новоутворення стають визначальною сферою професійної діяльності людини [2: 10-11];

по-друге, упровадженням моделі особистіснооріентованого навчально-виховного процесу як оновленої парадигми освіти, яка передбачає визнання студента суб'єктом цього процесу, носіем двох груп якостей через уміння навчатися та бажанням вчитися, що можливе за умови, з одного боку, оволодінням ним продуктивними уміннями і навичками та розгорнутою рефлексією, а 
з іншого - сорормованістю позитивного емоційноціннісного ставлення як до процесу діяльності, її результату, самореалізації особистості;

по-трете, особливою актуалізацією глобалізації усіх сорер життедіяльності особистості і суспільства в умовах загальноцивілізаційних тенденцій сучасного світу, що вимагає від вищої школи [3; 6-7] надати молодій людині елементарних можливостей інтегруватися в різні сощіуми, самовизначатися в житті, активно діяти, бути конкурентоспроможною на світовому ринку праці;

по-четверте, необхідністю опанувати мистецтвом швидких трансформаційних змін у освітніх системах як у локальному (регіональному, національному) середовищі, так і глобальному просторі.

Аналіз останніх досліджень і публікацій. Формування профресійної компетентності на етапі професійного розвитку в процесі навчання у виші в її різних аспектах постійно знаходиться в центрі уваги психолого-педагогічної науки. Ці питання знайшли відображення в дослідженнях таких вчених, як: С.А. Батишев, А.С. Белкін, В.П. Беспалько, М.М. Булинскій, А.А. Вербицький, Н.С. Глуханюк, В.В. Давидов, В.І. Загвязинский, Е.Ф. Зеер, Д.С. Срмаков, І.А. Зимова, П.Ф. Кубрушко, Н.В. Кузьміна, О.Є. Лебедев, А.К. Маркова, С.Є. Матушкин, Л.М. Митина, В.В. Серіков, В.А. Сластьонін, К.К. Платонов, Г.Н. Романцев, Н.Ф. Тализіна, Е.В. Ткаченко, А.М. Новиков, В.А. Федоров, Д.В. Чернілевський, В.Д. Шадриков, Т.І. Шамова, С.Є. Шишов, Г.П. Щедровицький та ін.

Увага багатьох дослідників компетентнісного підходу зосереджена в основному на теоретико-методологічних засадах проблеми [4; 5]. У наукових працях розкрито соціокультурні [3], профресійно-діяльнісні аспекти [2; 5] цієї проблеми, у педагогічних концепціях і теоріях обгрунтовано необхідність компетентнісної освіти. На думку О. Овчарук, перехід до компетентністного підходу потребуе опрацювання нового теоретичного базису, ідентифрікації поняттевого фронду європейської педагогічної термінології, зрозумілої всім учасникам освітнього процесу [3, с. 48].

Виділення не вирішених раніше частин загальної проблеми. Дані дослідження сприяли визначенню методологічних підходів і систематизащії знань 3 досліджуваної нами проблеми. Однак аналіз психолого-педагогічної літератури показав, що поза рамками виконаних наукових робіт залишилися:

- теоретичне обірунтування питань можливості досягнення заданого рівня сформованості профресійної компетентності фрахівців безпосередньо в процесі навчання у виші, що забезпечуе їм майбутне успішне здійснення продесійної діяльності (конкурентні переваги і профресійну мобільність);

- обгрунтування системи принципів і вимог до співвідношення рівня знань, навичок і умінь; особистісних i профресійно важливих якостей, образного i логічного мислення; теоретичного і практичного інтелекту; їх взаємозв'язку і взаємозумовленості в процесі профресійної підготовки у вищому навчальному закладі.

Мета статті. Головною метою ціеї роботи $є$ розробка концепції подолання теоретичних невизначеностей реалізації компетентнісного під- ходу, визначивши науково-методологічні основи підвищення ефрективності професійної підготовки державних і муніципальних управлінців.

Виклад основного матеріалу. Сам принцип компетенції зародився в рамках одніеї з конкретних наук i був згодом впроваджений в як науковий метод, який застосовується до різних сорер знання, включаючи педагогіку. Поняття «компетентнісний підхід» набуло поширення порівняно недавно в зв'язку 3 дискусіями про проблеми та шляхи модернізації освіти. Компетентнісний підхід - це пріоритетна орієнтація на цілі-вектори освіти: здатність до навчання, самовизначення, самоактуалізація, соціалізація і розвиток індивідуальності.

На думку О.Є. Лебедєва, компетентнісний підхід - це сукупність загальних принципів визначення цілей освіти, відбору змісту освіти, організації освітнього процесу та оцінки освітніх результатів [6]. Спочатку, коли на початку 80-х років минулого століття в педагогіці зародилася ідея компетентнісного підходу [7], мова йшла не про підхід, а про компетентність, профресійної компетентності, профресійних компетенціях особистості як мети і внаслідок утворення. Д.С. Срмаков визначає компетентнісний підхід як метод моделювання цілей і результатів освіти як норм його якості, відображення результату освіти в цілісному вигляді системи ознак готовності випускника до здійснення тієї чи іншої діяльності [8].

У педагогічному словнику слово «компетентність» - це здатність фрахівця застосовувати знання для вирішення практичних завдань відповідно до його компетенції, тобто колом повноважень, професійних обов'язків, питань, в яких дана людина досить обізнаний, маючи в своєму розпорядженні необхідною інформацією та практичним досвідом.

Розглянемо склад мотиваційної компетенції в галузі навчання фрахівців докладніше.

1. Аксіологічний компонент включає наступні елементи.

Мета:

- пізнання (опанувати наукової і навчальної інформацією навчитися ставити і вирішувати проблеми, знаходити способи вирішення проблем);

- навчальної діяльності (навчитися ставити перед собою цілі навчання, визначати способи їх досягнення, оволодіти навчальними діями, навчитися здійснювати самоконтроль і самооцінку);

- спілкування в освітніх ситуащіях (навчитися слухати співрозмовника, вести діалог, проявляти толерантність).

Ціннісні оріентації:

- спрямованість на розширення кругозору, оволодіння іноземною мовою, отримання освіти тощо;

- спрямованість на оволодіння способами пізнання;

- спрямованість на розвиток навчальної діяльності;

- спрямованість на самовдосконалення властивостей і якостей індивідуальності та особистості;

- спрямованість на саморозвиток мотивації;

- спрямованість на компетентнісний поведінку.

2. Узагальнено такий компонент, як гностичний, який включає знання і уявлення:

- про сутність мотивації та її складових; 
- про види мотивів, цілей, цінностей в сcpepi навчання;

- про особистісно значущих і суспільно значущих мотивах;

- про властивості мотивації (нестійкість, керованість, динамізм тощо);

- про фрактори та умови розвитку мотивації;

- про способи самопізнання мотивації (мотиваційних стоянь, мотивів, ціннісних орієнтацій, потреб тощо);

- про способи саморозвитку мотивацї̈;

- про критерії оцінки мотиваційної компетентності.

Поняття «компетенція» - ємне і складне. Воно описуе зв'язки між елементами людської діяльності. На думку деяких дослідників, слід говорити не про ключові компетенції, а про компетентність, яку умовно можна назвати «здатністю до діяльності», яка включае готовність до цілепокладання, оцінки, дії, рефлексії.

Всі ключові компетенції, на думку фрахівців, мають такі характерні ознаки:

1. Багатофрункціональність. Оволодіння компетенціями дозволяе вирішувати різні проблеми в повсякденному, професійної або соціальної життя. Ключові компетенції необхідно застосовувати для успішного досягнення поставлених цілей і вирішення різноманітних завдань, що виникають в різних ситуаціях.

2. Міждисциплінарність. Використовуються в різних ситуаціях - не тільки у виші, але й на роботі, в сім'ї, в політичній та інших сорерах життя.

3. Обумовленість рівнем інтелектуального розвитку людини: абстрактного мислення, саморефлексії, самооцінки, критичного мислення.

4. Багатомірність. Ключові компетенщії включають різні розумові процеси та інтелектуальні вміння (аналітичні, критичні, комунікативні тощо).

У структуру державних освітніх стандартів вищої профресійної освіти включені інноваційні принципи організації навчального процесу, такі як дворівнева модель навчання, система заліково-кредитних одиниць і модульних технологій навчання. Тут надаються величезні можливості для вишів в реалізації різних принципів в освітній діяльності.

Компетентнісний підхід стимулює розвиток нових технологій оцінки якості освіти. Саме результати навчання, а не дидактичні одиниці змісту освіти стануть нормою його якості. В даний час вже в оцінці якості освіти ставиться не просто подача готових знань, а активна пізнавальна і практична робота самих студентів. Професійна затребуваність фрахівців на ринку праці - це головна думка Болонського процесу і одна з основних цілей створення єдиної системи європейської вищої освіти, в рамках якої вирішуються проблеми мобільності трудових ресурсів.

Продресійна компетентність фрахівців будьякого профілю включає в себе наступні різновиди:

- практична (спеціальна) компетентність високий рівень знань, техніки і технологій, що використовуються в профресійній праці і забезпечують можливість професійного зростання фрахівця, зміну профілю роботи, результативність творчої діяльності;

- соціальна компетентність - здатність брати на себе відповідальність і приймати рішення, брати участь в спільному прийнятті рішень, регулювати конфрлікти ненасильницьким шляхом, продуктивно взаємодіяти 3 представниками інших культур і релігій;

- психологічна компетентність - це культура емоційної сприйнятливості, уміння і навички редрлексії, досвід емпатійного міжособистісного взаємодії і самореалізаціі;

- екологічна компетентність, заснована на знанні загальних законів розвитку природи і суспільства, на екологічної відповідальності за профресійну діяльність;

- валеологічна компетентність, що означає наявність знань і умінь в області збереження здоров'я і в питаннях здорового способу життя.

Профресійна компетентність грунтується на володінні фрахівцем всією сукупністю культурних зразків, відомих до теперішнього часу в даній області людської діяльності. У міру їх освоєння в процесі профресійного становлення особистості завдання профресійної діяльності слід розглядати як частину культури, а суб'єкта, що реалізуе ці завдання - як фрахівця, що володіє профресійною культурою.

В процесі навчання фрахівців у ВНЗ слід використовувати активні форми і методи навчання 3 метою реалізації компетентнісного підходу: метод проектів, рольові ігри, дебати, пошукові ситуації, роботу в групах, проблемно-орієнтоване навчання, модульно-рейтингове навчання.

3 метою контролю якості навчальних досягнень студентів в умовах переходу ВНЗ на компетентнісно-орієнтовану освіту можна використовувати в навчальному процесі:

- введення в практику обов'язкової публічного захисту курсової роботи;

- створення банків тестових завдань для міждисциплінарного тестування, спрямованого на виявлення залишкових знань і базових компетенцій випускників ВНЗ;

- перехід до прийому екзаменів у формі демонстрації композицій (захисту проектів, презентацій компетенціі);

- введення в практику навчання комплексних екзаменів (інтегрованих, міждисциплінарних), які передбачають вирішення профресійних завдань і практичних ситуащій, починаючи 3 другого курсу;

- включення комплексного кваліфрікаційного екзамену в підсумкову державну атестацію з використанням практико-оріентованих завдань інтегративного характеру.

Переорієнтація змісту освіти на освоєння ключових компетенції, на наш погляд, відповідає і традиційних цінностей освіти (орієнтація на розуміння наукової картини світу).

Перевага компетентнісного підходу полягає в тому, що він дозволяє зберігати гнучкість і автономію в структурі і змісті навчального плану. Виходячи з цього, можна зробити висновок, що на сьогоднішній день система вищої освіти повинна більше спиратися на особистісно-орієнтовану, генезісну модель освіти, яка форомуе компетентності, ніж просто на передачу знань та формування певного набору навичок.

Висновки i пропозиції. На сьогоднішній день фрахівець - це не тільки людина, що володіє багажем спеціальних знань, а той, хто вміе ці знання застосувати, але, що ще більш важли- 
во, він повинен вміти приймати відповідальні рішення, проявляти ініціативу, мати навички управління інформацією і бути толерантним до культурним відмінностей.

Отже, перехід до компетентнісного підходу у вищій освіті дозволяє не просто накопичувати знання 3 дисциплін, що викладаються, а й стимулюе творче, креативне їх використання, що дозволяє студенту бути мобільним в освітньому середовищі, як країни, так і світу, а випускникові вишу стати затребуваним і конкурентноспроможним на ринку пращі.

Таким чином, компетентнісний підхід - це основа державних освітніх стандартів нового покоління i, як наслідок, принцип формування змісту освітніх програм вищої профресійної освіти.

\section{Список літератури:}

1. Новиков А.М. Культура как основание содержания образования. Педагогика. 2011. № 6. С. 3-14.

2. Солодков В. Соціальна сутність і структура дій Європейського простору вищої освіти. Післядиплолна освіта в Україні. 2007. № 1. С. 27-35.

3. Компетентнісний підхід у сучасній освіті: Світовий досвід та українські перспективи / за заг. ред. О.В. Овчарук. Київ : К.I.C., 2004. 112 с.

4. Десятов Т.М. Національні рамки кваліфрікацій у країнах ЄC: порівняльний аналіз : наук.-метод. посіб. Київ : Артек, 2008. 263 с.

5. Луговий B.І. Європейська концепція компетентнісного підходу у вищій школі та проблеми ії реалізації в Україні. Педагогіка і психологія : Науково-теоретичний та інфорлаиійний журнал. 2009. № 2. С. 13-25.

6. Лебедев О.Е. Компетентностный подход в образовании. Школьныле технологии. 2004. № 5. С. 3-12.

7. Ландшеер В. Концепция «минимальной компетентности». Перспективы: Вопросы образования. 1988. № 1. C. 27-34.

8. Ермаков Д.С. Педагогическая концепция формирования әкологической компетентности учащихс : автореф. д-ра пед. наук. Москва, 2009. 39 с.

\section{References:}

1. Novikov A.M. (2011) Kul'tura kak osnovaniye soderzhaniya obrazovaniya [Culture as the basis of content of education]. Pedagogy, no. 6, pp. 3-14

2. Solodkov V. (2007) Sotsial'na sutnist' i struktura diy Yevropeys'koho prostoru vyshchoyi osvity [Social essence and structure of the European Space of Higher Education]. Postgraduate Education in Ukraine, no. 1, pp. 27-35.

3. Ovcharuk O.V. (2004) Kompetentnisnyy pidkhid u suchasniy osviti: Svitovyy dosvid ta ukrayins'ki perspektyvy [Competent approach in modern education: world experience and Ukrainian prospects]. Kyiv: K.I.S. (in Ukrainian)

4. Desyatov T.M. (2008) Natsional'ni ramky kvalifikatsiy u krayinakh YES: porivnyal'nyy analiz [National qualifications framework in EU countries: comparative analysis]. Kyiv: Artek. (in Ukrainian)

5. Lugovyy V.I. (2009) Yevropeys'ka kontseptsiya kompetentnisnoho pidkhodu u vyshchiy shkoli ta problemy yiyi realizatsiyi v Ukrayini [The European Concept of a Competent Approach in Higher School and Problems of His Implementation in Ukraine]. Pedagogy and Psychology: Scientific and Theoretical and Information Journal, no. 2, pp. 13-25.

6. Lebedev O.Ye. (2004) Kompetentnostnyy podkhod v obrazovanii [Competent subordinate in order]. School technologies, no. 5, pp. 3-12.

7. Landsheyer V. (1988) Kontseptsiya «minimal'noy kompetentnosti» [Concept of "Minimal competence"]. Perspectives: Education Issues, no. 1, pp. 27-34.

8. Yermakov D.S. (2009) Pedagogicheskaya kontseptsiya formirovaniya ekologicheskoy kompetentnosti uchashchikhsya [Pedagogical concept of the formation of ecological competence of students] (PhD Thesis), Moscow: GOUVPO "Peoples' Friendship University of Russia". 